\title{
Manajemen Nyeri Kronis pada Kehamilan
}

\author{
Budi Yulianto Sarim, Bambang Suryono \\ Departemen Anestesiologi dan Terapi Intensif Fakultas Kedokteran, Kesehatan Masyarakat dan Keperawatan \\ Universitas Gadjah Mada-RSUP Dr. Sardjito Yogyakarta
}

\begin{abstract}
Abstrak
Menurut IASP ( International Association of the Study of Pain) nyeri didefinisikan sebagai "an unpleasant sensory and emotional experience associated with actual or potential tissue damage or describe interm of such damage". Nyeri adalah rasa inderawi dan pengalaman emosional yang tidak menyenangkan akibat adanya kerusakan jaringan yang nyata atau yang berpotensi rusak atau sesuatu yang tergambarkan seperti itu.Kelainan muskuloskeletal yang sering dialami oleh wanita hamil adalah berupa nyeri lumbopelvis pada kehamilan (pelvic girdle pain) dan nyeri kronis lumbal (low back pain).Adapun yang menyebabnya adalah faktor hormonal, faktor mekanis dan vaskuler. Manajemen untuk nyeri kronis pada wanita hamil dapat dilakukan melalui manajemen non farmakologis dan manajemen farmakologis. Manajemen non farmakologis dapat dikerjakan dengan cara fisioterapi, terapi distraksi, terapi musik, guided imaginary dan relaksasi. Untuk manajemen farmakologis, obat - obatan yang dapat diberikan adalah asetaminofen, NSAID dan analgesik opioid.
\end{abstract}

Kata kunci: manajemen nyeri kronis pada wanita hamil; nyeri kronis pada kehamilan; nyeri sekeliling pelvis kronis; nyeri lumbar kronis

\section{Management Chronic Pain in Pregnancy}

\begin{abstract}
According to the IASP (International Association of the Study of Pain) pain is defined as "an unpleasant sensory and emotional experience associated with actual or potential tissue damage or describe the interim of such damage". Pain is a sensation and or emotional experience unpleasant and disturbing as a result of tissue damage, or potential tissue damage. Musculoskeletal disorders are often experienced by pregnant women is pelvic girdle pain and chronic pain lumbar. The etiology of that is the hormonal factor, mechanical factors and vascular factors. Management of chronic pain in pregnancy can be done through non-pharmacological management and pharmacological management. Non pharmacological management can be done by means of physiotherapy, distraction therapy, music therapy, guided imaginary and relaxation. For pharmacological management can be given is acetaminophen, NSAIDs and opioid analgesics.
\end{abstract}

Key words: chronic pain in pregnancy; chronic pelvic girdle pain; chronic low back pain; chronic pain management in pregnancy 


\section{Pendahuluan}

Menurut IASP (International Association of the Study of Pain) nyeri didefinisikan sebagai "an unpleasant sensory and emotional experience associated with actual or potential tissue damage or describe interm of such damage". Nyeri adalah rasa inderawi dan pengalaman emosional yang tidak menyenangkan akibat adanya kerusakan jaringan yang nyata atau yang berpotensi rusak atau sesuatu yang tergambarkan seperti itu. ${ }^{1,2}$ Wanita hamil pada umumnya mengeluh adanya gangguan muskuloskeletal. Keluhan tersebut bisa bersifat ringan dan sembuh dengan sendirinya, kadang-kadang juga keluhan tersebut akan hilang pada beberapa orang. Gangguan muskuloskeletal pada wanita hamil pada umumnya disebabkan oleh banyak hal. Kelainan muskuloskeletal yang sering dialami oleh wanita hamil adalah berupa nyeri pelvis pada kehamilan (pelvis bagian belakang) dan nyeri kronis lumbal (low back pain). ${ }^{4-8}$

\section{Tinjauan pustaka}

\section{Nyeri Lumbopelvis (pelvic girdle pain) pada Kehamilan}

Nyeri lumbopelvis pada kehamilan merupakan keluhan paling sering dikeluhkan pada wanita hamil; daerah yang sering dikeluhkan meliputi 2 area yaitu area lumbal (low back pain) dan bagian belakang pelvis (mulai dari sacroiliac joint menyebar ke bawah sampai paha) sering pula disebut dengan nyeri sekeliling pelvis (pelvic girdle pain). Nyeri lumbopelvis pada kehamilan terjadi pada sekitar 50\% wanita hamil dan dapat mengganggu aktivitas sehari-hari termasuk pola tidur. Prevalensi nyeri daerah lumbopelvis pada kehamilan di negara Skandinavia dan negara lain sekitar 25\%-70\%. ${ }^{9,12,22,24}$

Wanita hamil dengan nyeri lumbopelvis dilaporkan lebih sering mengalami gangguan aktivitas selama kehamilan dibandingkan dengan hanya nyeri daerah lumbal. Sangat penting untuk membedakan antara nyeri lumbopelvis dan low back pain karena adanya perbedaan manajemen dan kecacatan yang ditimbulkan. Pada nyeri lumbopelvis umumnya kecacatan yang ditimbulkan sampai 1-2 tahun paska persalinan..$^{9,12,22,24}$

Faktor risiko terjadinya nyeri lumbopelvis pada kehamilan termasuk riwayat low back pain, usia muda, pergerakan sendi yang berlebihan, kelompok sosial ekonomi rendah, multiparitas, jatuh berguling dari tempat tidur, menaiki tangga, perubahan posisi dari duduk menjadi berdiri secara tiba-tiba (termasuk masuk dan keluar mobil, bath tub, tempat tidur), mengangkat barang sambil membungkuk dan spondilolistesis. Meskipun demikian faktor terpenting untuk terjadinya nyeri lumbopelvis pada kehamilan adalah riwayat nyeri lumbal (low back pain) sebelum hamildan pekerjaan berat yang dilakukan. Wanita yang memiliki riwayat nyeri lumbopelvis dalam kehamilan mempunyai risiko lebih tinggi untuk mengalami hal yang sama pada kehamiilan berikutnya. ${ }^{9,12,22,24}$ Sebagai penyebab terjadinya nyeri lumbopelvis dalam kehamilan adalah faktor hormonal, faktor mekanis dan vaskular.

\section{Hormonal}

Korpus luteum menghasilkan dan melepaskan hormon relaksin, dan konsentrasi hormon tersebut dalam darah wanita meningkat 10 kali lipat selama masa pembuahan. Hormon relaksin mengakibatkan pelunakan ligamen perifir dan menurunkan kekuatan pada sendi pelvis, hal ini mengakibatkan ketidakstabilan simfisis pubis dan sendi sakroiliaka. Derajat ketidakstabilan dan kecacatan yang ditimbulkan berhubungan erat dengan kadar relaksin dalam darah ibu. Terdapat hubungan antara kadar relaksin dengan kejadian nyeri punggung belakang selama kehamilan, pada umumnya wanita dengan gejala kelumpuhan yang berat memiliki kadar relaksin yang sangat tinggi. ${ }^{9} 12,22,24$

\section{Faktor Mekanis}

Perubahan mekanik memiliki onset yang lebih lambat dibandingkan perubahan hormonal. Wanita dengan nyeri sekeliling pelvis (pelvic girdle pain) memiliki peningkatan pergerakan sendi pelvis, hal ini menyebabkan terjadinya peningkatan tekanan yang sangat besar pada seluruh persendian dan akhirnya menimbulkan 
nyeri. Pembesaran uterus pada semua wanita hamil mengakibatkan berputarnya sakrum kearah depan dan meningkatnya lordosis lumbal, hal ini dapat menyebabkan lebih tertutupnya ruang interlamina didaerah lumbal. ${ }^{22,24}$

Perubahan ini menimbulkan tekanan yang sangat besar pada tulang pelvis baik pada daerah persendian maupun pada diskus intervertebralis. Sciatica dapat terjadi sekitar $1 \%$ pada wanita hamil, dan pada umumnya terjadi pada umur kehamilan lanjut. Sciatica dibedakan dengan nyeri sekeliling pelvis (pelvic girdle pain) melalui nyeri yang ditimbulkan sciatica pada umumnya menyebar sampai pergelangan kaki atau telapak kaki dan dapat diikuti dengan perubahan neurologis. Jadi perubahan hormonal mengakibatkan disfungsi sendi sakroiliaka, hal ini mengakibatkan nyeri lumbopelvis pada awal kehamilan. Perubahan mekanik menyebabkan nyeri yang terjadi pada umur kehamilan lebih lanjut, walaupun ketidaksatbilan simfisis pubis dan sendi sakroiliaka dapat menyebabkan juga nyeri yang berkepanjangan. ${ }^{4,22,24,29}$

\section{Vaskular}

Uterus gravid dapat mengakibatkan penekanan pada aorta dan vena kava terutama diantara L1-L5. Pertambahan volume ini disebabkan karena adanya peningkatan retensi air sekitar 8,5

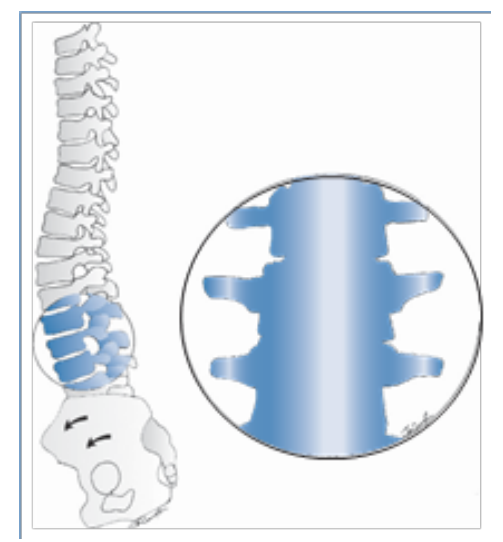

Gambar 1. Perubahan Mekanis ${ }^{22}$

liter selama kehamilan. Kompresi yang terjadi pada vena kava yang disebabkan oleh karena hipervolemia dapat menimbulkan penurunan kardiak out put, hipotensi dan peningkatan frekwensi nadi. $22,24,29$ Akibat yang ditimbulkan dari peningkatan aliran darah ke organ-organ pelvis, distensi vena yang disebabkan oleh hormon progesteron dan tidak adekuatnya kolateral vena pada bagian distal, dapat menyebabkan terjadinya iskhemi dan gangguan metabolik, hal ini dapat menstimulasi timbulnya nyeri lumbopelvis pada kehamilan.

\section{Nyeri Lumbal Kronis (chronic low back pain) pada Kehamilan}

Nyeri lumbal merupakan masalah yang umum dialami setiap wanita, tetapi terjadi peningkatan insidennya pada saat hamil. Prevalensi nyeri lumbal pada kehamilan sekitar $50 \%$ dan dapat meningkat menjadi sekitar $75 \%$ terutama pada trimester akhir kehamilan. Sekitar 57\%

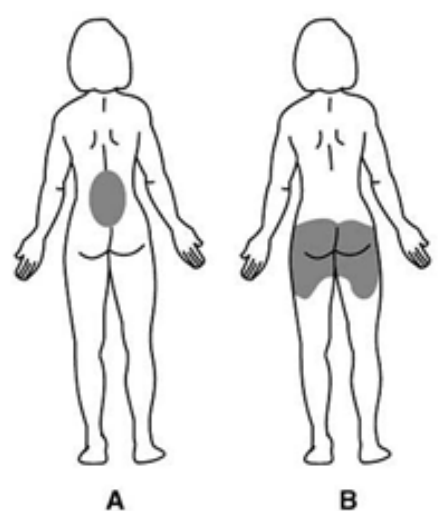

Gambar 2. Distribusi nyeri. A. Nyeri lumbal B. Nyeri lumbopelvis $^{24}$

wanita hamil mengeluh nyeri lumbal yang berat sehingga dapat mengganggu aktifitas sehari - hari. Sebagian besar wanita hamil dengan nyeri lumbal kronis mengalami gangguan tidur akibat dari nyeri yang ditimbulkan(58\%). . $2,22,24,29^{2}$ Adapun penyebab dari nyeri lumbal kronis belum diketahui dengan pasti, tetapi diduga penyebab timbulnya nyeri lumbal kronis sama dengan penyebab terjadinya nyeri lumbopelvis pada kehamilan, hanya beda pada distribusi nyerinya. Riwayat nyeri lumbal pada kehamilan sebelumnya, aborsi berulang dan perokok dapat merupakan faktor risiko terjadinya nyeri lumbal kronis. Brynhildsen dan kawan-kawan dalam penelitiannya yang melakukan follow up dalam 
waktu yang lama menemukan bahwa $94 \%$ wanita hamil dengan nyeri lumbal selama kehamilannya saat ini akan mengakibatkan nyeri lumbal juga pada kehamilan berikutnya. Ostgaard dan kawan - kawan dalam penelitiannya menemukan bahwa insiden nyeri lumbal pada wanita hamil adalah $50 \%$ lebih besar pada wanita yang memiliki riwayat nyeri lumbal sebelumnya dibandingkan wanita tanpa riwayat nyeri lumbal. Faktor risiko lain yang masih menjadi bahan perdebatan adalah umur dan jumlah paritas. . $12,22,24,29^{2}$

\section{Manajemen Nyeri Kronis pada Kehamilan}

Manajemen nyeri kronis pada kehamilan dapat dilakukan dengan non farmakologis atau konservatif dan farmakologis. Pasien awalnya menginginkan terapi terfokus pada farmakologis, walaupun secara umum terapi non farmakologis menawarkan manfaat yang lebih banyak. ${ }^{8,11,18,19}$

Manajemen Non Farmakologis

Manajemen non farmakologis nyeri kronis pada wanita hamil dapat dilakukan dengan cara: fisioterapi, terapi distraksi, terapi musik, guided imaginary dan relaksasi.

\section{Fisioterapi}

Fisioterapi ini berfokus pada modifikasi postur tubuh, peregangan, terapi manual, mobilisasi diri, kesadaran mekanika tubuh simetris, rehabilitasi fungsionil dan memperkuat otot tubuh. ${ }^{18,19}$ Beberapa studi menunjukkan bahwa wanita hamil dengan LBP yang mendapatkan tindakan fisioterapi dapat menurunkan tingkat intensitas rasa sakit, kecacatan dan memberikan kualitas hidup yang lebih baik, juga menunjukkan perbaikan pada kondisi fisik. ${ }^{18,19,20,24}$ Tujuan utama dari terapi manual dan mobilisasi di kehamilan adalah untuk mencapai dan memelihara keselarasan panggul. Rehabilitasi fungsionil melibatkan latihan di rumah dimana pasien hamil dapat melakukan sebagai bagian dari kegiatan sehari-hari. Seperti berdiri di satu kaki sementara di wastafel kamar mandi akan membantu memperkuat otot gluteus medius. Inti penguatan melibatkan kontrol otot-otot sekitar lumbal yang berfungsi menstabilkan tulang belakang. ${ }^{18,19,20,24}$ Latihan stabilisasi tubuh termasuk didalamnya a) menjaga postur tubuh yang baik selama kehamilan; b) pergerakan tubuh spesifik untuk pekerjaan - pekerjaan rutin yang dilakukan seperti pekerjaan rumah tangga sehari - hari, posisi tidur; c) latihan di rumah sesuai umur kehamilannya; d) tehnik mengatasi nyeri secara mandiri dan mobilisasi selama kehamilan. Jika tidak bisa menjaga postur tubuh yang baik dan menjaga posisi tulang belakang yang baik akan dapat mengakibatkan penarikan otot dan menimbulkan tekanan berlebihan pada tulang belakang. Jika berlangsung terus menerus akan dapat merubah karakteristik anatomi tulang belakang, kemungkinan diikuti juga konstriksi pembuluh darah dan saraf, masalah yang sama juga akan timbul di otot, diskus dan persendian. Semuanya ini dapat mengakibatkan nyeri pada daerah leher dan tulang belakang seperti nyeri kepala, lemah, dan kemungkinan juga menagkibatkan gangguan fungsi organ vital dan pernafasan. ${ }^{5,17}$ Postur tubuh yang baik akan membuat posisi tulang belakang

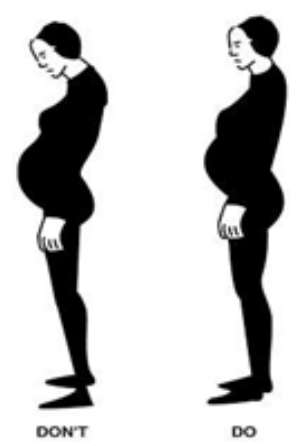

Gambar 3. Postur Tubuh selama Hamil1 ${ }^{7}$

baik sehingga dapat mengurangi insiden dan tingkat keparahan nyeri tulang belakang serta nyeri leher baik pada wanita hamil ataupun tidak $^{15,17}$.

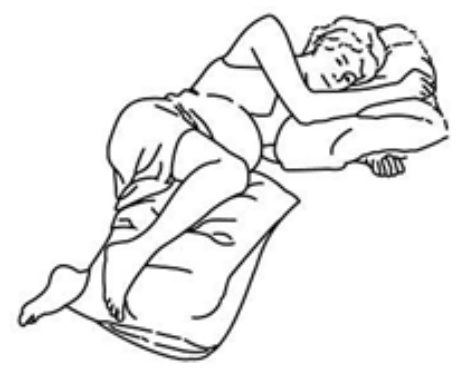

Gambar 4. Posisi Tidur ${ }^{17}$ 
<smiles>CC(=O)Nc1ccc(O)cc1</smiles>

Gambar 5. Rumus Bangun Asetaminofen ${ }^{6}$ $\mathrm{N}-(4-h y d r o x y p h e n y l)$ acetamide

Distraksi ${ }^{8,11,15,17}$ Teknik distraksi adalah teknik yang dilakukan untuk mengalihkan perhatian klien dari nyeri. Teknik distraksi yang dapat dilakukan adalah melakukan hal yang sangat disukai, melakukan kompres hangat pada bagian tubuh yang dirasakan nyeri, bernapas lembut dan berirama secara teratur, menyanyi berirama dan menghitung ketukannya.

\section{Terapi Musik}

Terapi musik adalah proses interpersonal yang digunakan untuk mempengaruhi keadaan fisik, emosional, mental, estetik dan spiritual, untuk membantu klien meningkatkan atau mempertahankan kesehatannya. Terapi musik digunakan oleh individu dari bermacam rentang usia dan dengan beragam kondisi; gangguan kejiwaan, masalah kesehatan, kecacatan fisik, kerusakan sensorik, gangguan perkembangan, penyalahgunaan zat, masalah interpersonal dan penuaan. ${ }^{8,11,15,17}$

\section{Guided Imaginary}

Yaitu upaya yang dilakukan untuk mengalihkan persepsi rasa nyeri dengan mendorong pasien untuk mengkhayal dengan bimbingan. ${ }^{8,11,15,17}$

\section{Relaksasi}

Teknik relaksasi terutama efektif untuk nyeri kronik dan memberikan beberapa keuntungan, antara lain mnurunkan ansietas yang berhubungan dengan nyeri atau stres, menurunkan nyeri, menolong individu untuk melupakan nyeri, meningkatkan periode istirahat dan tidur, meningkatkan keefektifan terapi nyeri lain, menurunkan perasaan tak berdaya dan depresi yang timbul akibat nyeri. Teknik relaksasi didasarkan kepada keyakinan bahwa tubuh berespon pada ansietas yang merangsang pikiran karena nyeri atau kondisi penyakitnya. Teknik relaksasi dapat menurunkan ketegangan fisiologis. Relaksasi ini mudah dilakukan dan tidak berisiko. ${ }^{8,11,15,17}$

\section{Manajemen Farmakologis}

Manajemen nyeri kronis pada wanita hamil sebaiknya meminimalis penggunaan obatobatan dan jika memungkinkan menggunakan pendekatan non farmakologis. Jika menggunakan obat - obatan, harus mempertimbangkan ikatan obat dengan protein plasma, kelarutan obat dalam lemak, kecepatan metabolisme dalam tubuh ibu dan berat molekul obat tersebut, karena hal tersebut mempengaruhi transfer obat dari ibu ke janin melalui plasenta. ${ }^{1,3,15,16}$

Asetaminofen

Asetaminofen banyak digunakan sebagai obat analgetik dan antipiretik, kombinasi asetaminofen dengan opioid dapatdigunakan untuk penanganan nyeri berat paska pembedahan dan terapi paliatif pada pasien-pasien penderita kanker. Onset analgesia dari asetaminofen adalah 8 menit setelah pemberian intravena, efek puncak tercapai dalam 30-45 menit dan durasi analgesia 4-6 jam serta waktu pemberian intravena 2-15 menit. Asetaminofen termasuk dalam kelas "aniline analgesics" dan termasuk dalam golongan obat anti inflamasi nonsteroid (masih ada perbedaan pendapat). Asetaminofen memiliki efek anti inflamasi yang sedikit dibandingkan denga NSAID lainnya. Akan tetapi asetaminofen bekerja dengan melalui mekanisme yang menyerupai dengan obat NSAID lainnya (menghambat sintesa prostaglandin). Dosis pada orang dewasa sebesar 500-1000 mg, dengan dosis maksimum direkomendasi $4000 \mathrm{mg}$ perhari $^{3,6,8}$

Mekanisme kerja utama dari asetaminofen adalah menghambat siklooksigenase (COX) dan selektif terhadap COX-2. Analgetik dan antipiretik dari asetaminofen sebanding dengan aspirin dan obat NSAID lainnya, akan tetapi aktifitas anti inflamasi perifernya dibatasi oleh beberapa faktor, diantaranya kadar peroksida yang tinggi di lesi inflamasi. Asetaminofen menurunkan 
bentuk oksidasi dari enzim COX yang melindungi dari pembentukan kimiawi bentuk pro inflammatory. Ini juga akan menurunkan jumlah dari prostaglandin E2 di SSP, akibatnya menurunkan batas ambang hipotalamus di pusat termoregulasi. ${ }^{6,8}$

Asetaminofen menghambat kerja COX dengan dua jalur, yang pertama bekerja dengan cara menghambat COX-3 (variant dari COX-1). Enzim COX-3 ini hampir sama dengan enzim COX lainnya dengan menghasilkan kimiawi pro- inflammatory dan penghambat selektif oleh asetaminofen. Jalur kedua bekerja seperti aspirin dengan memblok siklooksigenase, dimana didalam lingkungan inflamasi dengan konsentrasi peroksida yang tinggi dan melindungi aksi kerja asetaminofen dalam keadaan oksidasi tinggi. Ini berarti bahwa asetaminofen tidak memiliki efek langsung pada tempat inflamasi, akan tetapi bereaksi di SSP dimana keadaan lingkungan tidak teroksidasi. Bioavailibilitas dari asetaminofen adalah $100 \% .{ }^{3,6,8}$ Asetaminofen dimetabolisme di hati dengan tiga jalur metabolik, yakni glucuronidation $40 \%$, sulfation $20-40 \%$ dan N-hydroxylation serta GSH konjugasi 15\%, dengan obat dan metabolitnya diekskresikan melalui ginjal. ${ }^{3,6,8}$

Asetaminofen tidak memiliki sifat teratogenik, tidak menghambat sintesis prostaglandin atau fungsi trombosit dan bersifat hepatotoksik hanya bila digunakan dalam dosis yang sangat besar. Jika nyeri tetap persisten sehingga diperlukan penggunaan analgesik ringan selama kehamilan maka asetaminofen menjadi obat pilihan pertama yang aman dan efektif . Asetaminofen dipercaya amandigunakan pada wanita hamil (tidak mempengaruhi penutupan ductus arteriosus), tidak sepertiefek yang ditimbulkan oleh penggunaan obat NSAID. ${ }^{6,8}$

\section{Non Steroid Analgetic Drug (NSAID)}

NSAID (Non Steroidal Anti Inflammatory Drugs) atau obat anti inflamasi non steroid (AINS) adalah suatu kelompok obat yang berfungsi sebagai anti inflamasi, analgetik dan antipiretik. NSAID ini efektif untuk nyeri yang bersifat akut. Obat golongan NSAID dinyatakan sebagai obat anti inflamasi non steroid, karena ada obat golongan steroid yang juga berfungsi sebagai anti inflamasi. Obat golongan steroid bekerja dengan cara menghambat konversi fosfolipid menjadi asam arakhidonat melalui penghambatan terhadap enzim fosfolipase. . $, 3,6,11$

Sebagian besar efek terapi dan efek samping NSAID berdasarkan atas penghambatan biosintesis prostaglandin (PG). Pada saat sel mengalami kerusakan, maka akan dilepaskan beberapa mediator kimia. Di antara mediator inflamasi, prostaglandin adalah mediator dengan peran terpenting. Enzim yang dilepaskan saat ada rangsang mekanik maupun kimia adalah prostaglandin endoperoksida sintase (PGHS) atau siklo oksigenase (COX) yang memiliki dua sisi katalitik. Sisi yang pertama adalah sisi aktif

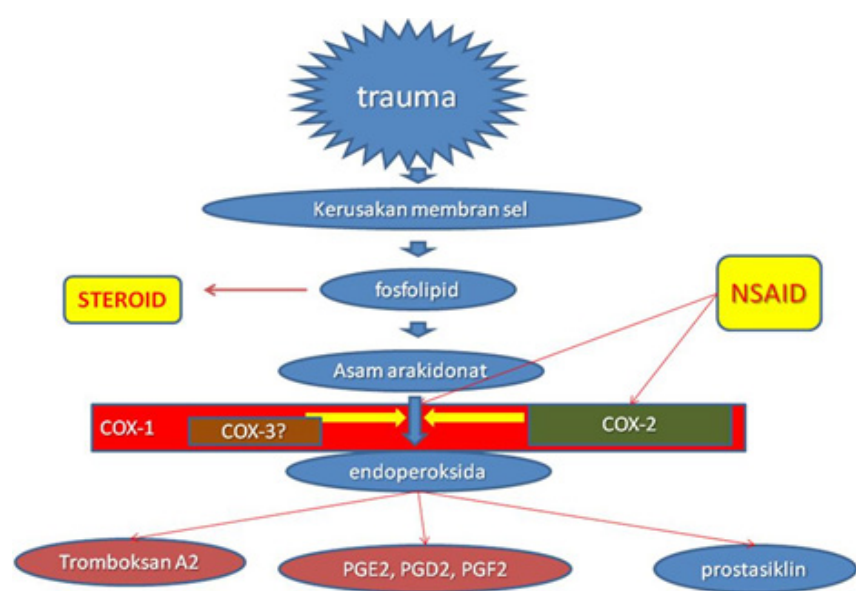

Gambar 6. Biosintesis Prostaglandin ${ }^{6}$ 
siklo oksigenase, yang akan mengubah asam arakhidonat menjadi endoperoksid PGG2. Sisi yang lainnya adalah sisi aktif peroksidase, yang akan mengubah PGG2 menjadi endoperoksid lain yaitu PGH2. PGH2 selanjutnya akan diproses membentuk PGs, prostasiklin dan tromboksan A2, yang ketiganya merupakan mediator utama proses inflamasi. COX terdiri atas dua isoform yaitu COX-1 dan COX-21,3,6,11. Golongan obat ini menghambat enzim siklo oksigenase (COX) sehingga konversi asam arakhidonat menjadi PGG2 terganggu. Setiap obat menghambat dengan cara berbeda. Khusus parasetamol, hambatan biosintesis prostaglandin hanya terjadi bila lingkungannya rendah kadar peroksida seperti di hipotalamus. Lokasi inflamasi biasanya mengandung banyak peroksida yang dihasilkan oleh leukosit. Ini menjelaskan mengapa efek anti inflamasi asetaminofen praktis tidak ada. Inhibisi biosintesis prostaglandin oleh aspirin

Tabel 1. FDA Pregnancy Risk Classification for Pain Management Medications ${ }^{1}$

\begin{tabular}{|c|c|c|}
\hline FDA Classification & Definition & Examples \\
\hline Category A & $\begin{array}{l}\text { Controlled human studies have indicated no ap- } \\
\text { parent } \\
\text { risk to the fetus. The possibility of harm to the } \\
\text { fetus }\end{array}$ & Multivitamins \\
\hline Category B & $\begin{array}{l}\text { Animal studies have not indicated fetal risk or } \\
\text { animal } \\
\text { studies have indicated teratogenic risk, but well- } \\
\text { controlled human studies have failed to } \\
\text { demonstrate a risk. } \\
\text { Studies have indicated teratogenic or embryocidal }\end{array}$ & $\begin{array}{l}\text { Acetaminophen } \\
\text { Caffeine } \\
\text { Metoprolol } \\
\text { Prednisolone, prednisone }\end{array}$ \\
\hline Category C & $\begin{array}{l}\text { Studies have indicated teratogenic or embryocidal } \\
\text { risk in animals, but no controlled studies have } \\
\text { been } \\
\text { conducted in women; there have been no con- } \\
\text { trolled } \\
\text { studies in animals or humans. }\end{array}$ & $\begin{array}{l}\text { Aspirin, ketorolac } \\
\text { Butorphanol, nalbuphine* } \\
\text { Codeine, fentanyl, hydrocodone, } \\
\text { methadone, meperidine, morphine, } \\
\text { oxycodone, oxymorphone* } \\
\text { Ibuprofen,naproxenindomethacint } \\
\text { Ibuprofen,naproxen,fluoxetine, } \\
\text { duloxetine, Gabapentin, pregabalin } \\
\text { Lidocaine, mexiletine } \\
\text { Nifedipine } \\
\text { Propranolol }\end{array}$ \\
\hline Category D & $\begin{array}{l}\text { There has been positive evidence of human fetal } \\
\text { risk, } \\
\text { but in certain cases the benefits of the drug may } \\
\text { outweigh the risks involved. }\end{array}$ & $\begin{array}{l}\text { Sumatriptan } \\
\text { Amitriptyline, imipramine } \\
\text { Diazepam } \\
\text { Paroxetine } \\
\text { Phenobarbital } \\
\text { Phenytoin }\end{array}$ \\
\hline Category X & $\begin{array}{l}\text { There has been positive evidence of significant } \\
\text { fetal risk, } \\
\text { and the risk clearly outweighs any possible ben- } \\
\text { efit. }\end{array}$ & $\begin{array}{l}\text { Valproic acid } \\
\text { Ergotamine }\end{array}$ \\
\hline
\end{tabular}


Tabel 2. Classification of Maternal Medication Use during Pregnancy ${ }^{1}$

\begin{tabular}{|c|c|c|}
\hline Classification & Definition & Examples \\
\hline Category 1 & $\begin{array}{l}\text { These medications should not be consumed during } \\
\text { lactation. Strong evidence exists that serious adverse } \\
\text { effects on the infant are likely with maternal ingestion } \\
\text { of these medica- }\end{array}$ & Ergotamine \\
\hline Category 2 & Category 2 & $\begin{array}{l}\text { Amitriptyline, desipramine, dox- } \\
\text { epin, fluoxetine }\end{array}$ \\
\hline Category 3 & These medications are compatible with breastfeeding. & $\begin{array}{l}\text { Diazepam, lorazepam, midazol- } \\
\text { am Carbamazepine, phenytoin, } \\
\text { valproate Atenolol, propranolol, } \\
\text { diltiazem } \\
\text { Codeine, fentanyl, methadone, } \\
\text { morphine, } \\
\text { propoxyphene Butorphanol Lido- } \\
\text { caine, mexiletine Acetaminophen } \\
\text { Ibuprofen, indomethacin, ketoro- } \\
\text { lac, naproxen } \\
\text { Caffeine }\end{array}$ \\
\hline Category 3 & These medications are compatible with breastfeeding. & $\begin{array}{l}\text { Diazepam, lorazepam, midazol- } \\
\text { am Carbamazepine, phenytoin, } \\
\text { valproate Atenolol, propranolol, } \\
\text { diltiazem } \\
\text { Codeine, fentanyl, methadone, } \\
\text { morphine, } \\
\text { propoxyphene Butorphanol Lido- } \\
\text { caine, mexiletine Acetaminophen } \\
\text { Ibuprofen, indomethacin, ketoro- } \\
\text { lac, naproxen } \\
\text { Caffeine }\end{array}$ \\
\hline
\end{tabular}

Dikutip: Adapted from American Academy of Pediatrics Committee on Drugs. Transfer of drugs and other chemicals into human milk. Pediatrics.2001;108:776-789.

menyebabkan asetilasi yang irreversibel di sisi aktif siklo okigenase, sedangkan sisi aktif peroksidase tidak terpengaruh.

Berlawanan dengan aksi aspirin yang irreversibel, NSAID lainya seperti ibuproven atau indometasin menyebabkan penghambatan terhadap COX baik reversibel maupun irreversibel melalui kompetisi dengan substrat, yaitu asam arakhidonat. Selama kehamilan, prostaglandin mempunyai banyak peranan, termasuk merangsang aktivitas uterus, menjaga patensi duktus arteriosus pada janin (penting untuk menjaga aliran darah dalam uterus tetap adekuat), dan menstimulasi produksi urin janin (memberikan kontribusi jumlah cairan ketuban pada trimester kedua dan ketiga). ${ }^{1,3,6,11}$ Perubahan metabolisme prostaglandin itu memiliki efek yang bervariasi pada kehamilan, tergantung pada waktu dan durasi penggunaan.

Misalnya, penggunaan jangka pendekindometasin pada trimester kedua efektif untuk pengobatan nyeri yang disebabkan oleh degenerasi jaringan fibrosit; jika digunakan dalam jangka waktu lama (lebih dari 48 jam) pada trimester ketiga berhubungan dengan terjadinya penyempitan duktus arteriosus dan oligohidramnion., ${ }^{1,3,6,11}$ Secara umum, jika menggunakan NSAID harus diberikan dalam jangka waktu singkat (kurang dari 48 jam) tanpa memerlukan monitoring aliran darah pada duktus janin dan volume cairan ketuban. Semua penggunaan NSAID untuk nyeri tidak boleh diberikan pada usia kehamilan 34 
Tabel 3. Guidelines for Use of NSAIDs during Pregnancy ${ }^{1}$
- C onsider nonpharmacologic management or acetamino- phen use first.
- $\quad \mathrm{C}$ onsider use of a mild opioid or opioid-acetaminophen combination analgesic.
- C ontinue aspirin or other NSAID if the symptoms cannot be controlled non pharmacologically or with acetaminophen alone.
- I nstitute close fetal monitoring during the second trimester. If high doses of NSAIDs are re- quired, periodic fetal ultra- sound, including fetal echocardiography, should be used to monitor amniotic fluid volume and patency of the ductus arteriosus.
- D iscontinue NSAID use after weeks 34 to 36 to reduce the risk for peripartum bleeding, neona- tal hemorrhage, and persistent fetal circulation.

NSAID, nonsteroidal anti-inflammatory drug

minggu untuk mencegah terjadinya hipertensi pulmonal pada bayibaru lahir. ${ }^{1,3,6,11}$ Aspirin dengan sifat menghambat plateletnya secara teoritis dapat meningkatkan risiko untuk terjadinya perdarahan peripartum. Fungsi trombosit pada neonatal dihambat hingga 5 hari setelah bayi dilahirkan dari ibu yang mendapatkan pengobatan aspirin. Akan tetapi terapi aspirin dosis rendah (60 sampai $80 \mathrm{mg} /$ hari) tidak berhubungan dengan komplikasi yang terjadi pada ibu atau bayi, tetapi penggunaan dengan dosis yang lebih tinggi tampaknya meningkatkan risiko untuk terjadinya perdarahan intrakranial pada bayi baru lahir sebelum umur kehamilan 35 minggu.

Penggunaan aspirin dosis rendah telah digunakan untuk meningkatkan output kehamilan pada wanita dengan preeklampsia dan antibodi antifosfolipid. Aspirin sama seperti NSAID lainnya yaitu dapat melewati barier plasenta. Meskipun belum terlihat dapat menyebabkan kelainan bawaan, tetapi berhubungan dengan adanya peningkatan risiko gangguan pembuluh darah terutama terjadinya gastroskhisis3.

\section{Analgesik Opioid}

Kelompok obat yang memiliki sifat seperti opium. Opium yang berasal dari getah Papaver somniferum mengandung sekitar 20 jenis alkaloid diantaranya morfin, kodein, tebain, dan papaverin. Analgesik opioid terutama digunakan untuk meredakan rasa nyeri yan bersifat kronis, meskipun juga memperlihatkan berbagai efek farmakodinamik yang lain.

\section{Reseptor Opioid}

Ada tiga jenis reseptor opioid yaitu $\mathrm{mu}(\mu)$,

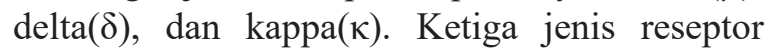
termasuk pada jenis reseptor yang berpasangan dengan protein $\mathrm{G}$, dan memiliki bermacam macam subtipe: mu1, mu2, delta1, delta2, kappa1, kappa2, dan kappa3. Karena suatu opioid dapat berfungsi dengan potensi yang berbeda sebagai suatu agonis, agonis parsial, atau antagonis pada lebih dari satu reseptor atau subtipe reseptor maka senyawa yang tergolong opioid dapat memiliki efek farmakologik yang beragam. Reseptor $\mu$ memperantarai efek analgesik mirip morfin, euphoria, depresi pernafasan, miosis, dan berkurangnya motilitas saluran cerna. Reseptor $\kappa$ diduga memperantarai analgesia seperti yang ditimbulkan pentazosin, sedasi serta miosis dan depresi nafas yang tak sekuat agonis $\mu$. Selain itu disusunan saraf pusat juga didapatkan reseptor $\delta$ yang selektif terhadap enkefalin dan reseptor $\varepsilon$ (epsilon) yang sangat selektif terhadap beta-endorfin tetapi tidak mempunyai afinitas terhadap enkefalin. ${ }^{1,3,5,10}$ Reseptor $\delta$ memegang peranan dalam menimbulkan depresi pernapasan yang ditimbulkan opioid. Penelitian pada tikus didapatkan bahwa reseptor $\delta$ dihubungkan dengan berkurangnya frekuensi napas, sedangkan reseptor $\mu$ dihubungkan dengan berkurangnya tidal volume. Reseptor $\mu$ ada dua jenis yaitu reseptor $\mu 1$, yang hanya didapat di SSP dan dihubungkan dengan analgesia supraspinal, pengelepasan prolaktin, hipotermia, dan katalepsi. Sedangkan reseptor $\mu 2$ dihubungkan dengan penurunan tidal volume dan bradikardia. Analgesik yang berperan pada tingkat spinal berinteraksi dengan reseptor $\delta$ dan $\kappa^{1,3,5,10}$ 
Tabel 4. Kerja opioid pada Reseptor Opioid ${ }^{5}$

\begin{tabular}{llll}
\hline Obat & Reseptor & $\mu \quad \delta($ delt a) & $\kappa$ (kappa ) \\
& $(\mathrm{mu})$ & Agonis & \\
\hline $\begin{array}{l}\text { Peptida opioid } \\
\text { Enkefalin }\end{array}$ & Agonis & Agonis & \\
$\beta$-endorfin & Agonis & & Agonis lemah \\
Dinorfin & Agonis lemah & Agonis lemah & \\
Agonis & Agonis lemah & Agonis lemah & \\
Kodein & Agonis & & \\
Morfin & Agonis & & Agonis \\
Metadon & Agonis & & Agonis \\
Meperidin & Agonis & & Antagonis \\
Fentanil & Agonis parsial & & \\
Agonis-antagonis & Antagonis & & \\
Buprenorfin & Agonis parsial & & \\
Pentazosin & Antagonis & & \\
& Antagonis & & \\
Nalbufin & & & \\
Antagoni & & & \\
Nalokson & & & \\
\hline
\end{tabular}

\section{Mekanisme Kerja}

Tipe Reseptor

Seperti yang telah dituliskan, tiga golongan reseptor opioid yang utama $(\mu, \delta, \kappa)$ telah dikenali pada berbagai tempat dalam sistem saraf dan jaringan lainnya. Semuanya merupakan reseptor terkopel-protein $\mathrm{G}$ dan menunjukkan sekuens asam amino yang sangat homolog. Menurut kriteria farmakologik, telah diajukan berbagai subtipe reseptor, termasuk $\mu 1, \mu 2, \delta 1, \delta 2, \kappa 1, \kappa 2$, dan $\kappa 3$ namun, sampai sejauh iniberbagai genyang hanya menyandi satu subtipe dari setiap keluarga reseptor $\mu, \delta$, dan $\kappa$ telah berhasil diisolasi dan diperinci. Satu penjelasan yang dapat diterima adalah bahwa subtipe reseptor $\mu$ muncul dari varian splice alternatif gen yang sama. Karena suatu opioid berpotensi memiliki berbagai fungsi sebagai agonis, agonis parsial, atau antagonis pada lebih dari satu golongan reseptor atau subtipe, tidak mengherankan jika agen-agen ini memiliki berbagai efek farmakologik. ${ }^{1,3,5,10}$

\section{Efek Seluler}

Pada tingkat molekular, reseptor-reseptor opioid merupakan sekeluarga protein yang secara fisik berkopel dengan protein $G$, dan melalui mekanisme ini, mempengaruhi gerbang kanal ion, memodulasi disposisi Ca2+ intrasel, dan mengubah fosforilasi protein. ${ }^{1,3,5,10}$ Opioid mempunyai dua efek langsung terkopel protein $G$ pada saraf: (1) opioid menutup kanal $\mathrm{Ca} 2+$ bergerbang-tegangan di ujung saraf parasimpatik sehingga menurunkan pembebasan transmiter, dan (2) opioid menghiperpolarisasi sehingga menghambat neuron paska sinaptik melalui pembukaan kanal $\mathrm{K}+$. Efek prasinaptik opioid, menekan pembebasan transmitter telah didemonstrasikan pada pembebasan neurotransmiter yang berjumlah banyak, seperti glutamat, suatu asam amino eksitatorik utama yang dibebaskan dari ujung saraf nosiseptif, begitu juga dengan asetilkolin, noripenefrin, serotonin, dan substansi P. ${ }^{1,3,5,10}$ Agonis $\mu$, $\delta$, dan $\kappa$ menurunkan pembebasan transmiter (glutamate dan neuropeptida eksitatoris) dari ujung prasinaps 
aferen prime $\mathrm{r}$ (badan sel dihilangkan). Agonis $\mu$ juga menghiperpolarisasi neuron penghantar rasa nyeri ordo kedua denganmeningkatkan konduktansi $\mathrm{K}+$, mencetuskan potensial inhibitorik pasca sinaps. ${ }^{1,3,5,10}$

Hubungan Efek Fisiologik dengan Jenis Reseptor Pada umumnya opioid analgesik yang saat ini ada dipasaran bekerja terutama pada reseptor opioid $\mu$. Berbagai efek morfin, seperti analgesia, euforia, depresi pernapasan, dan menimbulkan ketergantungan fisik, terutama timbul akibat kerjanya pada respetor $\mu$. Bahkan, reseptor $\mu$ pertama kali ditemukan menggunakan efekanalgesia klinis relatif dari serangkaian opioid alkaloid. Akan tetapi, efek analgesik opioid sangat kompleks dan melibatkan interaksi morfin dengan reseptor $\delta$ dan $\kappa$. Pernyataan ini didukung oleh studi perusakan (knockout) genetik pada gen $\mu, \delta$, dan $\kappa$ dalam mencit. ${ }^{1,3,5,10}$

Agonis reseptor $\delta$ memberikan efek analgesik pada mencit yang reseptor $\mu$ telah dirusak. Pengembangan agonis selektif reseptor $\delta$ dapat saja bermanfaat secara klinis jika efek sampingnya (depresi pernapasan, risiko ketergantungan) lebih ringan daripada efek samping agonis reseptor $\mu$ yang saat ini ada dipasaran,seperti morfin. Morfin memang bekerja pada reseptor $\kappa$ dan $\delta$, akan tetapi peranan kerja morfin ini pada efek analgesik masih belum jelas. Peptida opioid endogen berbeda dengan kebanyakan alkaloid dalam hal afinitas terhadap reseptor $\delta$ dan $\kappa^{1,3,5,10 .}$

Tabel 5. Analgesics for Moderate to Severe Pain during Pregnancy ${ }^{* 1}$

\begin{tabular}{lll}
\hline Drug & $\begin{array}{l}\text { Equianalgesic } \\
\text { Parenteral } \\
\text { Dose }\end{array}$ & $\begin{array}{l}\text { Equianalgesic } \\
\text { Oral Dose }\end{array}$ \\
\hline Fentanyl & $50 \mu \mathrm{g}$ & - \\
Hydromorphone & $1 \mathrm{mg}$ & $2-4 \mathrm{mg}$ \\
Morphine & $5 \mathrm{mg}$ & $30-60 \mathrm{mg}$ \\
Meperidine & $50 \mathrm{mg}$ & $150-300 \mathrm{mg}$ \\
\hline
\end{tabular}

*There is wide variability in the duration of analgesic action from patient to patient. All the parenteral agents listed are gener-ally started with dosing every 3 to 4 hours and the oral agents every 4 to 6 hours. The dosing interval can then be adjusted as needed to maintain adequate analgesia
Distribusi Reseptor dan Mekanisme Analgesik Dineuron

Reseptor utama opioid sangat banyak dijumpai di kornu posterior medulla spinalis. Reseptorreseptor ini terdapat dalam neuron penghantar di medulla spinalis dan aferen primer yang menyampaikan "pesan" nyeri pada neuron di medulla spinalis. Agonis opioid menghambat pembebasan transmiter eksitatorik dari aferen primer penghantar rasa nyeri. Selain itu, agonis opioid juga secara langsung menghambat neuron penghantar nyeri di medulla spinalis. Dengan demikian, opioid memiliki efek analgesic kuat yang bekerja secara langsung di medulla spinalis. Efek spinal ini telah dimanfaatkan secara klinis sebagai analgesic regional melalui pemberian langsung opioid analgesic pada medulla spinalis; efek ini cenderung lebih sedikit menimbulkan depresi napas, mual dan muntah, dan sedasi daripada efek pemberian opioid secara sistemik. ${ }^{1,3,5,10}$

Ketika diberikan secara sistematik, opioid pereda nyeri kemungkinan bekerja di sirkuit- sirkuit otak yang biasanya diatur oleh peptide opioid endogen. Sebagian dari efek pereda opiod eksogen ini melibatkan pembebasan peptida opioid endogen. Suatu agonis opioid eksogen (seperti morfin) mungkin bekerja terutama dan secara langsung di reseptor $\mu$, tapi kerja ini dapat mencetuskan pembebasan opoid endogen tambahan yang bekerja di reseptor $\delta$ dan $\kappa$. Jadi, bahkan suatu ligan yang selektif reseptor pun dapat memulai serangkaian kejadian kompleks yang melibatkan berbagai macam sinaps, transmiter, dan jenis reseptor. ${ }^{1,3,5,10}$ Sirkuit batang otak yang mendasari efek modulasi jaras desenden oleh analgesia yang diperantai reseptor opioid $\mu$ (MOR). Neuron penghambat rasa nyeri diaktifkan secara tidak langsung oleh opioid ( eksogen atau endogen ) yang menghambat inter neuron inhibitorik (GABA). Sehingga ini mengakibatkan peningkatan inhibisi proses nosiseptif di kornu posterior medulla spinalis Semua analgesik opioid sekarang termasuk risiko teratogenik kategori $\mathrm{C}$ bila digunakan dalam waktu yang singkat. Semua analgesik opioid termasuk berisiko kategori D bila digunakan untuk waktu yang lama selama kehamilan. 
Tabel 6. Oral Analgesics for Treating Pain during Pregnancy*1

*There is wide variability in the duration of analgesic action from patient to patient. All the oral agents listed are generally started with

\begin{tabular}{|c|c|c|c|}
\hline Drug & How Supplied & $\begin{array}{l}\text { Equianalgesic Oral } \\
\text { Dose }(\mathrm{mg})\end{array}$ & FDA Risk Category \\
\hline Acetaminophen & - & $\begin{array}{l}325-, 500-\mathrm{mg} \text { tablets; } \\
500 \mathrm{mg} / 15 \mathrm{~mL} \text { elixir }\end{array}$ & $\mathrm{BC} \dagger$ \\
\hline Codeine & 6 & & $\mathrm{C} \uparrow$ \\
\hline $\begin{array}{l}\text { Acetaminophen with } \\
\text { codeine }\end{array}$ & $\begin{array}{l}0 \\
-\end{array}$ & $\begin{array}{l}15-, 30-, 60-\mathrm{mg} \text { tablets; } \\
15 \mathrm{mg} / 5 \mathrm{~mL} \text { elixir }\end{array}$ & $\mathrm{C} \uparrow$ \\
\hline Oxycodone & $\begin{array}{l}1 \\
0\end{array}$ & $\begin{array}{l}5 \text {-mg tablets; } 5 \mathrm{mg} / 5 \\
\mathrm{~mL} \text { elixir }\end{array}$ & $\mathrm{C} \uparrow$ \\
\hline $\begin{array}{l}\text { Acetaminophen with } \\
\text { oxycodone }\end{array}$ & $\overline{2}$ & $\begin{array}{l}325 \cdot 5-, 500 \cdot 5-\mathrm{mg} \\
\text { tablets; } 325 \cdot 5 / 5 \mathrm{~mL} \\
\text { elixir }\end{array}$ & $\mathrm{C} \uparrow$ \\
\hline Morphine & 0 & & $\mathrm{C} \dagger$ \\
\hline Hydromorphone & 2 & $\begin{array}{l}15-, 30-\mathrm{mg} \text { tablets; } 10 \text {, } \\
20 \mathrm{mg} / 5 \mathrm{~mL} \text { elixir } \\
2-, 4-, 8 \text {-mg tablets; } 5 \\
\mathrm{mg} / 5 \mathrm{~mL} \text { elixir }\end{array}$ & $\mathrm{C} \uparrow$ \\
\hline
\end{tabular}

Peringatan peningkatan risiko ini disebabkan potensi ketergantungan opioid neonatal ketika ibu mendapat pengobatan dengan opioid untuk jangka waktu yang lama selama kehamilan.

Buprenorfin, sebuah $\mu$-opioid agonis parsial dan $\kappa$-opioid antagonis yang sering digunakan untuk pengobatan ketergantungan opioid tetapi saat ini lebih sering di gunakan untuk pengobatan nyeri kronis. Ahli kandungan dan ahli anestesi karena itu akan lebih sering mendapatkan pasien yang diobati dengan buprenorfin. Obat ini dalam dosis kecil sudah menimbulkan efek di reseptor sehingga risiko untuk terjadinya overdosis lebih kecil bila dibandingkan dengan metadon. Meskipun metadon telah digunakan selama lebih dari 40 tahun untuk pengobatan ketergantungan opioid tetapi sekarang lebih dianjurkan menggunakan buprenorfin sebagai obat pilihan pertama. ${ }^{1,3}$

Fentanil merupakan salah satu analgesik opioid parenteral yang paling sering diberikan selama periode perioperatif. Seperti pada semua analgesik opioid, pemberian fentanil untuk ibu dapat menyebabkan depresi pernafasan pada bayi.Pemberian fentanil atau opioid lain pada ibu hamil dapat menyebabkan hilangnya denyut jantung janin yang normal. Kehilangan denyut jantung janin yang normal merupakan tanda hipoksemia janin, sehingga pemberian opioid selama persalinan dapat menurunkan nilai apgar. ${ }^{1,3,5}$ Meperidine dimetabolisme dihepar menjadi normeperidine, dan memiliki waktu paruh yang panjang (18 jam). Apabila dilakukan pemberian berulang maka dapat menyebabkan terjadinya akumulasi khususnya pada pasien dengan insufisiensi ginjal. Normeperidine menyebabkan eksitasi disusunan saraf pusat dan manifestasinya dalam bentuk tremor, mioklonus, dan kejang umum. Akumulasi yang sangat tinggi dari normeperidine tidak mungkin terjadi pada ibu melahirkan yang mendapatkan dosis tunggal atau dosis pemberian yang jarang. Namun meperidin tidak memberikan keuntungan lebih banyak jika dibandingkan dari opioid parenteral lainnya. ${ }^{1,3,5,10}$ 
Pemberian analgesik paska operasi pada wanita hamil yang mengalami operasi non obstetrik dapat dengan mudah diberikan analgesi opioid. Fentanyl, morfin, dan hidromorfon merupakan opioid yang aman diberikan bila memerlukan opioid poten untuk pemberian secara parenteral. Analgesik narkotika juga dapat diberikan secara intratekal atau epidural sebagai analgesi paska operasi. Pemberian agen hidrofilik secara neuroaksial (misalnya, morfin) sangat mengurangi total pemberian opioid paska operasi dengan tujuan memberikan efek analgesi yang baik. Pemberian opioid melalui spinal atau epidural dalam proses persalinan dapat mengurangi konsentrasi plasma ibu sehingga dapat mengurangi perpindahan melalui melalui plasenta ke janin atau paparan melalui air susu ibu. ${ }^{1,3,5,10}$

\section{Penutup}

Menurut IASP (International Association of the Study of Pain ) nyeri didefinisikan sebagai "an unpleasant sensory and emotional experience associated with actual or potential tissue damage or describe interm of such damage". Nyeri adalah suatu sensasi dan atau pengalaman emosional yang tidak menyenangkan serta mengganggu sebagai akibat adanya kerusakan jaringan, atau yang berpotensi terjadinya kerusakan jaringan. Kelainan muskuloskeletal yang sering timbul pada wanita hamil adalah nyeri lumbopelvis (pelvic girdle pain) dan nyeri lumbal kronis (chronic low back pain) pada kehamilan. Adapun penyebab kelainan muskuloskeletal tersebut adalah faktor hormonal, faktor mekanis dan vaskular. Manajemen nyeri kronis pada kehamilan dapat dibedakan menjadi dua yaitu melalui manajemen non farmakologis dan farmakologis. Pada manajemen non farmakologis dapat dilakukan dengan cara fisioterapi, distraksi, terapi musik, guided imaginary dan relaksasi. Adapun manajemen farmakologis dapat diberikan asetaminofen, NSAID dan analgesik opioid.

\section{Daftar Pustaka}

1. Nagpal G, Rathmell JP. Managing Pain during
Pregnancy and Lactation. Dalam: Benson HT, Rathmell JP, Wu CL, Turk DC, Argof CE, Hurley RW (eds). Practical Management of Pain, 5thed. Philadelphia,Mosby Elseiver. 2014;35:474-91.

2. Borenstein D. Low Back Pain. Dalam: Waldman SD. Pain management, 2nd ed. Philadelphia, Saunders Elseiver, 2011; 87:695-700.

3. Thompson JA. Management of chronic pain. Dalam: Moppet IK, Thompson JA, Aitkenhead AR (eds). Smith and Aitkenhead's Textbook of Anaesthesia, 6th ed. Philadelphia, Churchill Livingstone Elseiver. 2013; 46:932-47.

4. Preston R. Musculoskeletal Disorder. Dalam: Nathan N, Myhre JM, Beilin Y,Ngan Kee WD,Tsen LC,Wong CA, Chestnut DH (eds). Chestnut'S obstetric anesthesia: Principles And Practice, 5th ed. Philadelphia, Saunders Elsevier, 2014;48:1093-1112.

5. Fukuda K. Opioids. Dalam: Young WL, Wiener-Kronish JP,Fleisher LA,Eriksson LI,Miller RD (eds). Miller's Anesthesia,7th ed. Philadelphia, Churchill Livingstone Elseiver, 2010;27:769-824.

6. Brogan S, Mandyam S, Drennan DA. Non-opioid analgesics. Dalam Egan TD, Hemmings $\mathrm{HC}$ (eds). Pharmacology and physiology for anesthesia foundations and clinical application. Philadelphia,Saunders Elseiver,2013;16:272-290.

7. Fitzgerald CM, Le J. Back pain in pregnancy requires practitioner creativity-Although this common condition isn't always treated, nonsurgical approaches can provide relief. Biomechanics 2007;39:547-551.

8. Babb M, Koren G, Einarson A. Treating pain during pregnancy. Can Fam Physician 2010;56(1):25-27.

9. Rebar, Robert W. Low back pain is common 
during pregnancy. NEJM Journal Watch. General Medicine 2004;27: 123-134.

10. Knotkova H, Fine P, Portenoy R. Opioid rotation: The science and the limitations of the equianalgesic dose table. Journal of Pain and Symptom Management, 2010; 38:426-39.

11. Childers, Christine. Preventing and managing back pain during pregnancy. Physical Therapy 2005;85:1107-110.

12. SenthilKP, Eva C.Pregnancy-related low back pain or gestational back pain: too complex to handle or too simple to ignore? Indian Journal of Obstetrics and Gynaecology 2013;1:87-89.

13. Eggen HM, Stuge B, Mowinckel P, Jensen KS, Hagen KB. Can supervised group exercises including ergonomic advice reduce the prevalence and severity of low back pain and pelvic girdle pain in pregnancy? A Randomized Controlled Trial.Physical Therapy 2012;92:781-90.

14. Broussard CS, Rasmussen SA, Reefhuis J. Maternal treatment with opioid analgesics and risk for birth defects. National Birth Defects Prevention Study. Am J Obstet Gynecol. 2011;204:314.

15. White KP. Breaking thru the fibromyalgia fog - scientific proof fibromyalgia is real. http:// www.healthline.com/health/fibromyalgiaand-pregnancy-expert-qa\#1

16. Stevie. Medication for chronic pain patients.http://chronicpainsite.com/ $\mathrm{pj} /$ ? gclid=CjwKEAiAh560BRDua D 93 r-J_zoS J A C r x Z G 205 4p2PLd1Ivxx4koXgNFpaGJHt3KNbGk_PspjFhoCycPw_wcB

17. Waterfield J, Bartlam B, Bishop A, Holden MA, Barlas P, Foster NE. Therapst's views and experiences of pregnancy-related low back pain and the role of acupuncture: qualitative exploration. Physical Therapy 2015;95:1234-243.
18. Vleeming A, Albert HB, Ostgaard HC. European guidelines for the diagnosis and treatment of pelvic girdle pain. EurSpineJ2008;17:794-19.

19. Gutke A, Ostgaard HC, Oberg B. Pelvic girdle pain and lumbar pain in pregnancy: a cohort study of the consequences in terms of health and functioning. Spine 2006;31:149-55.

20. Pool-Goudzwaard AL, Slieker ten Hove $\mathrm{MCPH}$, Vierhout ME, Snijders CJ, Stoeckart R, Pool JJM, Mulder PH. Relations between pregnancy-related low back pain, pelvic floor activity and pelvic floor dysfunction. Int Urogynecol J 2005;16:468-74.

21. Padua R, Bondi R, Ceccarelli. Patienyoriented assessment of back pain in pregnancy. Eur Spine J 2002;11: 272-75.

22. Jeffcot H. Exercises for low back pain in pregnancy. International Journal Childbirth Education 2008;23:9-12.

23. William WK, Margaret WN. Back pain symptomps and bone mineral density changes in pregnancy as measured by quantitative ultrasound. Gynecol Obstet Invest 2009;67:36-41.

24. Noren L, Ostgaard S, Johansson G. Lumbar back and posterior pelvic pain during pregnancy: a 3-year follow up. Eur Spine J 2002;11:267-71.

25. Bergstrom C, Persson M, Mogren I. Pregnancy-related low back pain and pelvic girdle pain approxiametly14 months after pregnancy-pain status, self related health and family situation. BMC Pregnancy and Childbirth 2014;14:1-12.

26. Smith MD, Russel A, Hodges PW. Is there a relationship between parity, pregnancy, back pain and incontinence? Int Urogynecol J 2008;19:205-11.

27. Padua L, Caliandro P, Aprile L. Back pain 
in pregnancy: 1-year follow-up of untreated cases. Eur Spine J 2005;14:151-54.

28. Robin R, Felicity R. Back pain, pregnancy and childbirth postpartum pain is most likely to be a continuation of antepartum pain.
British Medical Journal 1997;314:1062-064.

29. Sneag DB, Bendo JA. Review article pregnancy-related low back pain. http:// www.ORTHOSuperSite.com. 